\section{La penetración del antisemitismo nazi en la población del Tercer Reich}

Cristian Buchrucker

Cristian Buchrucker es Profesor de la Facultad de Filosofía y Letras / Instituto Multidisciplinario de Estudios

Sociales Contemporáneos (IIMESC), de la Universidad Nacional de Cuyo, e Investigador del CONICET.

e-mail: buchruckerc@logos.uncu.edu.ar

\section{Resumen}

En la década pasada D. Goldhagen («Hitler's Willing Executioners", 1996) generó un debate en torno a su tesis de que el antisemitismo de los nazis habría sido prácticamente "idéntico» al de la vasta mayoría del pueblo alemán. La confirmación documental de esa afirmación no se ha dado y otros estudiosos han emitido juicios bastante diferentes al respecto lvéanse por ej. H. Auerbach en W. Benz, "Legenden, Lügen, Vorurteile», 1992 y A. Lindemann, "Esau's Tears", 1997).

Las fuentes muestran un panorama altamente diferenciado, cuyos matices cubren todo el espectro que va desde la aceptación total del mensaje nazi y la complicidad activa con la política del régimen, hasta la oposición clara, con una fuerte cuota de riesgo personal. En lengua castellana son escasas las fuentes disponibles, lo que dificulta la elaboración de juicios críticos sobre una cuestión de innegable importancia para la formación especializada en historia contemporánea. Para contribuir a superar esa dificultad en el medio académico argentino, se presenta aquí la traducción y análisis crítico de una selección de esos materiales.
Este artículo presenta algunos de los resultados alcanzados en una línea de trabajo que se viene concretando desde 2000 en un Seminario sobre Racismo y Holocausto, que luego se integró en el programa de investigación $L a$ democracia y los nacionalismos en los conflictos del mundo contemporáneo (Ciclo 2005-2007, Universidad Nacional de Cuyo/ Facultad de FyL/ IMESCl. Fue discutido como ponencia en las XI Jornadas Interescuelas/ Departamentos de Historia, Tucumán, septiembre de 2007.

\section{Summary}

A decade ago D. Goldhagen («Hitler's Willing Executioners», 1996) generated a debate about his thesis that Nazi antiSemitism had been practically "identical» to the antiSemitism already present in the vast majority of the German people. Documental confirmation of this proposition has not been produced, and other researchers have very different views concerning this matter (see for example $\mathrm{H}$. Auerbach in W. Benz, "Legenden, Lugen, Vorurteile», 1992 and A. Lindemann, "Esaus Tears", 1997).

The sources show a highly diverse panorama, characterised by nuances that cover a broad spectrum, going from total acceptance of the Nazi message and active complicity with the regime policy, to a clear opposition including a strong quota of personal risk. Only few sources have been printed in Spanish language, a circumstance that hinders critical appraisals of a question of undeniable importance for the specialized training in contemporary history. The here presented translation and critical analysis of a selection of these materials should be seen as a contribution to the task of overcoming this difficulty in the Argentine academic milieu. 